Wydział Prawa i Administracji

Uniwersytet Warmińsko-Mazurski w Olsztynie

piotr529@wp.pl

Kamila GroszKowsKA

Sandler \& Travis Advisory Service

groszkowska.kamila@gmail.com

\title{
ENVIRONMENTAL MIGRATION IN INTERNATIONAL LAW AND POLITICS
}

\author{
ProblematyKa MIGRACJI KLIMATYCZNYCH \\ W POLITYCE I PRAWIE MIĘDZYNARODOWYM
}

\begin{abstract}
The topic of this article is the problem of no legal regulations regarding the status of environmental migrants and its implications. Neither does International law permit them to take advantage of legal protection granted to refugees, nor are their interests represented in any international document. The article presents the analysis of the works of United Nations, expert group and international organisations, which resulted in introducing the notions of migrants and people in vulnerable situations to the Preamble of, adopted at the climate conference in 2015, Paris Agreement, stressing the importance of promoting and respecting their rights. Moreover, it has been decided to create a special task force within the Warsaw International Mechanism for Loss and Damage, which aim is to draft recommendations on how to minimise the impact of climate change on migration. The article then proceeds to analyse the effectiveness of the actions undertaken by the task force as well as by other key actors, such as other UN departments, International Organisation for Migration or world leaders at G20 summits. The final part presents the assessment of said actions, indicating why they are insufficient and the model of preventing and reducing economical damage unsatisfactory.
\end{abstract}

\section{STRESZCZENIE}

Tematem artykułu jest problem braku prawnego uregulowania statusu migrantów klimatycznych i tego konsekwencje. Prawo międzynarodowe nie przyznaje im 
ochrony przeznaczonej dla uchodźców, a ich prawa nie są reprezentowane w żadnym międzynarodowym dokumencie. Celem artykułu jest przedstawienie prac Organizacji Narodów Zjednoczonych, grup eksperckich oraz organizacji międzynarodowych. Ich owocem było wprowadzenie pojęcia migrantów i osób w trudnej sytuacji do preambuły przyjętego na konferencji klimatycznej w 2015 r. porozumienia paryskiego. Zwrócono przy tym uwagę na konieczność promowania i respektowania ich praw. Ponadto, w porozumieniu zdecydowano o utworzeniu specjalnej grupy zadaniowej w ramach Warszawskiego Międzynarodowego Mechanizmu Strat i Szkód, której celem było opracowanie sposobów ograniczenia wpływu zmian klimatycznych na migracje. W dalszej części omówiono skuteczność działań tej grupy, struktur ONZ, jak również innych kluczowych podmiotów, tj. Międzynarodowej Organizacji ds. Migracji czy liderów na szczycie G20. W części końcowej przedstawiono ocenę tych działań, wykazując, dlaczego są one niewystarczające, a przyjęty model zapobiegania i redukowania szkód i strat gospodarczych zbyt wąski.

KEYWORDS: environmental migrants, climate changes, international politics, international law, human rights law

SŁOWA KLUCzOWE: migranci klimatyczni, zmiany klimatu, polityka międzynarodowa, prawo międzynarodowe, prawa człowieka

\section{WPROWADZENIE}

Każdego roku, nie tylko w tych ostatnich, naznaczonych kryzysem migracyjnym latach, miliony ludzi przemieszczają się z miejsc nienadających się już do życia w okolice pozwalające jeszcze egzystować i uprawiać ziemię. Te migracje, w odróżnieniu od innych, nie są powodowane czynnikami politycznymi, ekonomicznymi i/lub wojennymi, ale niemożliwością produkowania tego minimum żywności i dóbr podstawowych, które są niezbędne dla przeżycia człowieka. Najczęściej to wydłużające się okresy suszy lub nadmiar wód niszczy oczekiwane zbiory; w ten sposób całe populacje pozbawione są możliwości i nadziei dotrwania do nowego okresu produkcyjnego.

Głównym teatrem tego dramatu jest kontynent afrykański, ale sytuacja niewiele lepiej wygląda w wielu regionach Azji czy Ameryki Środkowej i Południowej. Przymuszeni przez naturę ludzie emigrują, a pojawiając się w nowym, obcym dla siebie miejscu, nazywani są uchodźcami klimatycznymi, gdyż ich ziemie nie są już im „życzliwe” i przestały wydawać plony. Najczęstszą tego przyczyną jest naturalna labilność klimatu. 
Tego rodzaju zmiany obserwowane są na całym świecie, również w naszych szerokościach geograficznych, ale na szczęście jeszcze nie w stopniu zmuszającym do masowego migrowania. W odniesieniu do tak złożonego zjawiska, jakim są postępujące zmiany klimatyczne, generujące masę trudności natury ekonomicznej, należy przynajmniej wspomnieć o etycznych implikacjach tego fenomenu, który jest jednocześnie i naturalny, i społeczno-polityczny.

Świadomość tego skłania m.in. do szukania konsensusu co do stopnia zależności pomiędzy zwielokrotnioną emisją dwutlenku węgla powodowaną gospodarczą i życiową aktywnością człowieka a skutkami stopniowych zmian w biosferze Ziemi. Sam fakt udziału człowieka w tych zmianach jest na tyle ewidentny, że w etyce coraz wyraźniej dostrzega się konieczność mówienia o odpowiedzialności indywidualnej i zbiorowej wobec dobra, jakim jest środowisko naturalne. To ekoetyczne przekonanie jest już na tyle powszechne, że można się z nim spotkać chyba wszędzie.

Świadomość etyczna powodowania szkód środowiskowych poskutkowała zmianami doktrynalnymi w substancji prawnej i politycznej, np. przyjęciem terminu „szkoda środowiskowa” i wprowadzaniem szeregu środków zaradczych oraz sankcji karnych wobec osób i instytucji, które się tego dopuszczają; konferencje międzynarodowe wypracowują cele i zadania, a organy weryfikujące kontrolują ich wypełnianie na poziomie krajowym i regionalnym.

\section{PraWo międzynarodowe A DEFINICJA UCHOdŹCY KLIMATYCZNEGO}

Migracje ludności powodowane czynnikami środowiskowymi nie są zjawiskiem nowym. Mimo to, pojęcie uchodźców klimatycznych pojawiło się w literaturze stosunkowo niedawno, bo dopiero w latach 80. ubiegłego wieku. Na przemieszczanie się ludzi w obrębie własnego kraju, jak i poza jego granice z reguły składa się wiele czynników, dlatego też trudno wskazać konkretne przyczyny tych migracji. W związku z wejściem do użycia pojęcia uchodźcy/ migranta klimatycznego pojawiła się konieczność jego zdefiniowania i określenia statusu prawnego takiej osoby.

Trzeba przede wszystkim zauważyć, że etyczno-prawny i polityczny zakres pojęciowy kategorii „uchodźca” (tak jak jest pojmowany przez prawo międzynarodowe i konwencje z tym związane) nie przystaje do tego, co kryje 
się pod terminem „uchodźca klimatyczny”. W tekstach prawnych, traktujących o uchodźcach, uciekinierach, azylantach, migrantach itp. niemal wyłącznie mówi się o osobach przemieszczających się z powodu ich przynależności etnicznej, ideologicznej bądź religijnej. Toteż w dokumentach prawa międzynarodowego pojęcie uchodźcy/migranta klimatycznego zaledwie się pojawia. Brakuje natomiast ogólnie przyjętej definicji. Jednym z głównych powodów braku jednomyślności w definiowaniu migracji indukowanych zmianami warunków środowiskowych są zawsze im towarzyszące (a często i dominujące) czynniki ekonomiczne. Chcąc zatem mówić o migracjach, należałoby najpierw wykazać, że zjawisko migracji klimatycznych w ogóle ma miejsce, co - jak się okazuje - nie zawsze jest takie oczywiste, ponieważ ostateczna decyzja o opuszczeniu dotychczasowego miejsca bytowania bardzo często wynika z przyczyn ekonomicznych, które z kolei są bezpośrednią konsekwencją wcześniej zaistniałych zmian klimatycznych (gdy np. permanentny lub okresowy brak wody nie pozwala już na uprawę roślin lub hodowlę zwierząt, pozbawiając tym samym ludzi możliwości wytwarzania czy zdobywania pożywienia). Wykazanie tych powiązań przyczynowo-skutkowych jest dość problematyczne, szczególnie że mamy do czynienia zarówno z migracją przymusową, jak i tą z wyboru. Próba zdefiniowania i sklasyfikowania migracji klimatycznych stanowi zatem punkt wyjścia dla osób zajmujących się tematem. Niestety uczestnicy debat na temat migracji klimatycznych zazwyczaj zajmują nieco różniące się między sobą stanowiska. Organizacje pozarządowe działają w kierunku zwiększenia świadomości społecznej, zwrócenia uwagi na skalę zjawiska i wykazania konieczności podjęcia szybkich i konkretnych działań. Organizacja Narodów Zjednoczonych (ONZ), Międzynarodowa Organizacja ds. Migracji (IOM, ang. International Organization for Migration) czy inne organizacje międzynarodowe są w tym ostrożniejsze, koncentrując się raczej na problemach wynikających z braku definicji. Środowiska akademickie z kolei zwracają uwagę na luki prawne i konieczność dostosowania porządku prawnego do nowych wyzwań.

Jedna z pierwszych definicji została zaproponowana w roku 1985. Zgodnie z nią „uchodźcy klimatyczni” to osoby zmuszone do tymczasowego lub stałego opuszczenia swojego naturalnego miejsca zamieszkania ze względu na (naturalne lub wywołane przez człowieka) negatywne zmiany środowiska 
naturalnego (w przypadku gdy zmiany te doprowadziłyby do zagrożenia ich życia lub poważnego obniżenia jego jakości).

Punktem wyjścia zazwyczaj jest charakter migracji (przymusowy lub dobrowolny, permanentny lub tymczasowy) a następnie jej zasięg (wewnętrzna czy transgraniczna). Kolejnym krokiem jest określenie, co wchodzi w zakres negatywnych zmian środowiska. Można tu dokonać rozróżnienia na katastrofy naturalne nagłe i stopniowo postępujące albo te, wywołane działaniami ludzi (Docherty i Gianni, 2009, s. 349-403).

Szczególnie problematyczne na gruncie prawa międzynarodowego jest pojęcia „uchodźca klimatyczny”; brak ogólnie przyjętej definicji prowadzi do nieścisłości w jego używaniu, ponieważ sugeruje ono, że osoby te mogą korzystać z międzynarodowej ochrony prawnej gwarantowanej konwencją genewską. W doktrynie przeważa pogląd, że konwencja ta nie może mieć zastosowania do tzw. migrantów klimatycznych, w związku z czym nazywanie tej grupy „uchodźcami” jest niewłaściwe i wprowadza pewne zamieszanie w prawie (Cournil, 2012, s. 360). Mimo to, część badaczy - nawet mając świadomość nieprzystawania tego określenia do międzynarodowego prawa uchodźczego - w języku potocznym i publicystyce nadal nazywa tych migrantów „uchodźcami” (Epiney, 2012, s. 388).

Koncepcja rozszerzenia zakresu konwencji genewskiej miała początkowo zwolenników. Pod koniec lat 90. ubiegłego wieku zaproponowano reinterpretację art. 25 Powszechnej Deklaracji Praw Człowieka, mówiącego o prawie do życia w dobrobycie, jak również rozszerzenia definicji uchodźcy w konwencji genewskiej na osoby żyjące w warunkach środowiskowych zagrażających życiu. Samo wprowadzenie zmian w konwencji byłoby stosunkowo łatwe do implementowania przez państwa członkowskie, które mają już gotowe mechanizmy ochrony prawnej uchodźców, jednakże takie rozwiązanie mogłoby doprowadzić do rozregulowania międzynarodowego systemu ochrony (Cournil, 2012, s. 366). Ostatecznie Biuro Wysokiego Komisarza Narodów Zjednoczonych ds. Uchodźców (UNCHR) zajęło stanowisko, uznając, że konwencja genewska nie ma zastosowania $\mathrm{w}$ innych sytuacjach niż prześladowania na gruncie rasowym, religijnym, narodowościowym czy politycznym. W związku z tym, osoby przemieszczające się z powodu zmian czy katastrof klimatycznych nie podlegają wynikającej z konwencji ochronie prawnej. 
Brak uregulowań prawnych na gruncie prawa międzynarodowego staje się tym większym problemem, im bardziej przybiera na sile zjawisko tej migracji. Zgodnie z przewidywaniami liczba migrantów klimatycznych w $2050 \mathrm{r}$. znacząco przewyższy liczbę uchodźców uprawnionych do ochrony na gruncie konwencji genewskiej (Docherty, Gianni, 2009, s. 349). Potrzeba sformułowania i uściślenia powszechnie obowiązującej definicji i zbudowania systemu ochrony prawnej dla migrantów klimatycznych staje się w związku z tym coraz bardziej nagląca.

\section{PODMIOTY PRAWA MIĘDZYNARODOWEGO A PROBLEM MIGRACJI KLIMATYCZNYCH}

Podmiotem najbardziej właściwym do uregulowania migracji powodowanych zmianami klimatu na poziomie międzynarodowym jest ONZ. W ostatnich latach szczególnie aktywne w tym zakresie były dwa jej organy: Biuro Wysokiego Komisarza Narodów Zjednoczonych ds. Uchodźców (UNCHR), a także Sekretariat w zakresie prac nad Ramową Konwencją Narodów Zjednoczonych w sprawie Zmian Klimatu (UNFCCC). Podczas 16 Konferencji Klimatycznej w Cancun (2010) podpisano Decyzję 1/CP.16', która dała podstawy do rozpoczęcia prac nad omawianą problematyką ${ }^{2}$. Zgodnie z art. 14(f) państwa członkowskie Konwencji mają podejmować działania dla zaznajomienia się ze stopniem wpływu zmian klimatycznych na migracje i koordynowania ich na poziomie regionalnym, narodowym i międzynarodowym. Na podstawie tej decyzji, jak również decyzji 3/CP.18, podjętej na konferencji klimatycznej w Doha $(2012)^{3}$, z inicjatywy UNCHR powołano grupę doradczą w zakresie zmian klimatycznych i mobilności (Advisory Group on Climate Change and Human Mobility) dla zapewnienia merytorycznego wsparcia UNFCCC w zakresie wpływu zmian klimatycznych na migracje ludzi, a także przedstawienia rekomendacji przed szczytem COP21 w Paryżu (2015). Zadaniem grupy było włączenie problematyki migracji klimatycznych w globalne negocjacje.

Grupa doradcza, w raporcie Human Mobility in the context of climate change UNFCC - Paris COP-21, przedstawiła zakres propozycji sposobów włączenia omawianej problematyki do tekstu porozumienia paryskiego oraz miejsca w dokumencie, w których powinny znaleźć się odniesienia do mi- 
gracji wywołanych niekorzystnymi dla człowieka zmianami klimatyczny$\mathrm{mi}^{4}$. Zdaniem ekspertów, niezbędne było wskazanie konieczności podjęcia działań zapobiegających i minimalizujących przemieszczanie się ludności już w preambule tekstu, jak również w art. 2, wskazującym na główne cele porozumienia. Migracje powinny zostać włączone w procedury traktujące o wpływie zmian klimatu na ludność, powinny się znaleźć - wraz z propozycją środków zaradczych - w zapisach dotyczących adaptacji, zapobiegania, ograniczania i usuwania strat i szkód. Grupa podała także przykłady działań średnioterminowych, mających m.in. udzielić wsparcia rządom państw członkowskich, władzom lokalnym czy organizacjom (sub)regionalnym przy włączaniu zmian klimatycznych do tworzonych strategii i planów działania, jak również - co szczególnie ważne - przy zapewnieniu finansowania działań związanych z migracjami klimatycznymi. Szczególny nacisk położono na ułatwianie migracji oraz planowe relokacje, które - jeżeli przeprowadzone w porozumieniu z zagrożonymi społecznościami - mogą przynieść dobre rezultaty w tworzeniu nowych, bezpiecznych środowisk życia i tym samym zmniejszać negatywny wpływ zmian klimatycznych na warunki życia.

Warto też zwrócić uwagę na wynik tzw. inicjatywy Nansen. Powstała dzięki wspólnym wysiłkom Norwegii i Szwajcarii, które po konferencji na temat klimatu i migracji zobowiązały się do opracowania międzynarodowej strategii działania ${ }^{5}$. Inicjatywę wsparły UNCHR oraz Unia Europejska. Potem dołączyli również przedstawiciele innych krajów. Jej celem nie było stworzenie projektu konwencji międzynarodowej czy opracowanie jakiegoś „miękkiego” instrumentu prawnego, ale wypracowanie konsensusu pomiędzy zaangażowanymi państwami. Inicjatywa skupiła się przede wszystkim na ochronie migrantów zmuszonych do szukania innego miejsca zamieszkania w wyniku katastrof naturalnych oraz na opracowaniu programów ochrony, które mogłyby zostać wykorzystane przez organizacje na poziomie regionalnym i międzynarodowym ${ }^{6}$. Jednym z nich był „Program ochrony migrantów transgranicznych w kontekście katastrof i zmian klimatu” (Agenda for the protection of cross-border displaced persons in the context of disasters and climate change). Główne jego założenia to kompleksowe opracowanie problematyki migracji klimatycznych, zebranie dobrych praktyk dla minimalizowania strat i ich zapobiegania oraz podkreślenie konieczności ścisłej 
współpracy na różnych poziomach: ochrony praw człowieka, prowadzenia akcji humanitarnych, zarządzania migracjami, ochrony uchodźców, zarządzania kryzysowego i przeciwdziałania skutkom zmian klimatycznych. Program ten wskazuje ponadto na trzy obszary priorytetowe, $\mathrm{tj}$.: tworzenie baz danych i gromadzenie wiedzy, zastosowanie systemu ochrony humanitarnej w kontekście „wysiedleńców klimatycznych” oraz wzmocnienie systemu zarządzania kryzysowego ${ }^{7}$ (F, s. 10).

\section{KWESTIA MIGRACJI KLIMATYCZNYCH W POROZUMIENIU PARYSKIM}

Prace grupy doradczej w zakresie zmian klimatycznych i mobilności oraz inicjatywy Nansen miały na celu przedstawienie rekomendacji na szczyt klimatyczny w Paryżu (2015), gdzie podpisano porozumienie paryskie - efekt globalnych negocjacji w sprawie zmian klimatycznych ${ }^{8}$. Główne postanowienia dotyczą emisji gazów cieplarnianych. Jest to jednocześnie pierwsze międzynarodowe, wiążące strony porozumienie, w którym pojawia się wzmianka o migrantach w kontekście zmian klimatu. Już $\mathrm{w}$ preambule tekstu wskazano na obowiązek poszanowania, promowania i uznania przyjętych przez strony obowiązków ochrony praw człowieka, praw migrantów oraz praw osób, które znalazły się w trudnym położeniu9 Ponadto, w projekcie decyzji CP.21 dotyczącej implementacji postanowień porozumienia, w par. 50, zapowiedziano powołanie $\mathrm{w}$ ramach Warszawskiego Międzynarodowego Mechanizmu Strat i Szkód specjalnej grupy zadaniowej (task force) złożonej z ekspertów akademickich, przedstawicieli organizacji międzynarodowych i pozarządowych, której zadaniem ma być opracowanie rekomendacji i strategii działania w celu zmniejszenia skutków i wpływu zmian klimatycznych na migracje ludności.

Międzynarodowa Organizacja ds. Migracji entuzjastycznie odniosła się do postanowień porozumienia paryskiego, uznając, że jest ono przełomem w podejściu do migracji klimatycznych w wymiarze międzynarodowym, chociażby z powodu uwzględnienia pojęcia „migrant” w preambule. Dzięki temu, problem - zdaniem IOM - został zauważony przez społeczność międzynarodową, która zrozumiała potrzebę podjęcia działań w tym zakresie ${ }^{10}$. Rzeczywiście, włączenie tematu migracji klimatycznych do negocjacji na fo- 
rum międzynarodowym jest krokiem naprzód, jednakże ostateczny kształt porozumienia paryskiego w tym zakresie jest rozczarowujący. Decyzje podjęte na konferencji wskazują, że problem ten powinien być włączony w procedury dotyczące strat i szkód. Można to uznać za sygnał dla kierunku działań i decyzji, jakie na przyszłość mają podejmować decydenci w tej sprawie. Trzeba też pamiętać, że zarówno preambuła, jak i cała reszta projektu decyzji nie są wiążące dla stron i nie nakładają na nie konkretnych obowiązków. Przewidziana w decyzji CP.21 inicjatywa utworzenia grupy zadaniowej ograniczyła się jedynie do wskazania ogólnych założeń, bez sprecyzowania, kiedy miałaby zostać utworzona, kto konkretnie powinien znaleźć się w jej składzie, jakie ma być źródło finansowania, ani tego, na jakich warunkach eksperci mieliby współpracować z pozostałymi organami międzynarodowymi zajmującymi się tym samym zagadnieniem. Niewiadomą pozostało również, kto ma być wykonawcą opracowanych przez grupę zadaniową rekomendacji, w jakim czasie mają być przedstawiane oraz czy będą wiążące dla ich adresatów.

\section{INNE INICJATYWY PODNOSZĄCE KWESTIĘ MIGRACJI KLIMATYCZNYCH}

W lutym 2016 r. w Bonn odbyło się drugie spotkanie Komitetu Wykonawczego Warszawskiego Międzynarodowego Mechanizmu Strat i Szkód, na którym zdecydowano o utworzeniu specjalnej grupy zadaniowej, zgodnie w wytycznymi porozumienia paryskiego ${ }^{11}$. Podczas czwartego spotkania Komitetu w 2016 r. ustalono zakres kompetencji grupy zadaniowej i rozpoczęto proces powoływania członków ${ }^{12}$. Grupa rozpoczęła pracę w 2017 r. W jej skład weszli przedstawiciele Komitetu Wykonawczego Warszawskiego Międzynarodowego Mechanizmu Strat i Szkód, Wysoki Komisarz Narodów Zjednoczonych ds. Uchodźców (UNHCR), członkowie Programu Narodów Zjednoczonych ds. Rozwoju (ang. United Nations Development Programme - UNDP), Międzynarodowej Federacji Towarzystw Czerwonego Krzyża i Czerwonego Półksiężyca, IOM, grupy doradczej w zakresie zmian klimatycznych i mobilności oraz Międzynarodowej Organizacji Pracy (International Labour Organisation - ILO $)^{13}$. Stosownie do postanowień porozumienia paryskiego, za cel działania grupy przyjęto opracowanie rekomendacji w zakresie wspólnych działań na rzecz zapobiegania, zmniejszania skutków oraz 
przeciwdziałania migracjom wywołanych negatywnym wpływem zmian klimatycznych ${ }^{14}$. Zgodnie z art. 6 zakresu kompetencji grupa zadaniowa miała w swoich rekomendacjach: uwzględniać najnowsze dane naukowe, działać zgodnie z funkcjami Warszawskiego Międzynarodowego Mechanizmu Strat i Szkód, opracowywać wspólne działania na poziomie regionalnym, narodowym i międzynarodowym, zidentyfikować wyzwania prawne, strategiczne, dobre praktyki postępowania, umożliwiać zainteresowanym stronom przedstawianie swoich pytań, propozycji oraz włączać w proces instytucje i grupy eksperckie w ramach Ramowej Konwencji Narodów Zjednoczonych w sprawie zmian klimatu. Na podstawie tych wytycznych grupa zadaniowa opracowała stosowny plan działań ${ }^{15}$. Podzielono go na cztery kategorie, tj.: opracowanie strategii na poziomie regionalnym oraz na poziomie międzynarodowym, zbieranie $\mathrm{i}$ analizowanie danych, a także tworzenie ram działania i przygotowywanie narzędzi do ich realizacji. Zgodnie z postanowieniami zakresu kompetencji, rekomendacje mają być przedstawione najpóźniej na COP24. tj. 24. szczycie klimatycznym w $2018 \mathrm{r}$.

W ramach struktury ONZ działania w zakresie migracji klimatycznych podejmowane są także z poziomu Biura ONZ ds. Ograniczania Ryzyka Katastrof (UN Office for Disaster Risk Reduction). W 2015 r., podczas 3. Konferencji Narodów Zjednoczonych w sprawie Redukcji Ryzyka Katastrof (Third UN World Conference on Disaster Risk Reduction) w Sendai, podpisano Ramowy Programu Działania na rzecz ograniczania ryzyka katastrof na lata 2015-2030 ${ }^{16}$. Jest to niewiążące prawnie porozumienie zakładające 15-letni plan działań w zakresie minimalizowania ryzyka katastrof. W ramach priorytetu trzeciego, tj. inwestowania w redukcję szkód, w art. 30 (l) zachęca się do wdrażania programów i strategii radzenia sobie ze skutkami migracji wywołanych katastrofami zgodnie $\mathrm{z}$ prawem narodowym państw członkowskich $-\operatorname{art.} 30(1)^{17}$.

Drugą, wcześniej wspomnianą instytucją zaangażowaną w problematykę migracji klimatycznych jest Międzynarodowa Organizacja ds. Migracji, która w 2015 r. utworzyła Sekcję ds. Migracji, Środowiska i Zmian Klimatu (Migration, Environment and Climate Change Division) dla sprawniejszego realizowania działań Organizacji w tym zakresie ${ }^{18}$. Stawiane przed nią trzy główne cele dotyczą: ograniczania przymusowej i niezorganizowanej migra- 
cji do minimum, zapewniania wsparcia i ochrony zmuszonym do przesiedlania się oraz ułatwiania migracji jako środka adaptacyjnego do zmian klimatycznych. Zadaniem podejmowanych przez IOM działań jest zwiększanie świadomości społeczności międzynarodowej na temat związku zmian klimatycznych z migracjami, a także wypracowywanie konkretnych środków ochrony dla ludzi zmuszonych z tego powodu do przesiedlania się. Zaplanowane przez IOM inicjatywy obejmują m.in. przygotowanie atlasu migracji klimatycznych i rekomendacji dla decydentów państw członkowskich oraz realizację współfinansowanego przez Unię Europejską Projektu Migracje, Środowisko i Zmiany Klimatu: Dowody dla Polityk (Migration, Environment and Climate Change: Evidence for Policy - MECLEP). Jednym z jego założeń jest wykorzystanie migracji i planowych relokacji jako środka adaptacyjnego dla osób dotkniętych skutkami zmian klimatycznych. Pozostałe działania obejmują szkolenia dla decydentów, twórców polityk i strategii w zakresie ich opracowywania i implementowania oraz wypracowywanie narzędzi operacyjnych do realizacji przyjętych środków ochrony prawnej. W marcu 2017 r. został też uruchomiony portal internetowy http://www.environmentalmigration.iom.int, z jednej strony będący bazą informacji, aktualnych danych i publikacji, z drugiej, wirtualną przestrzenią komunikowania, wymiany informacji i opinii.

Do uznania konieczności włączenia problematyki migrantów klimatycznych do globalnego dialogu wezwani zostali także światowi przywódcy. Podczas szczytu G20 w Hangzhou (2016), w wydanej przez siebie deklaracji ${ }^{19}$ liderzy państw uznali przymusową migrację za problem globalny; wezwali do zwiększenia pomocy humanitarnej dla uchodźców i zobowiązali się do podjęcia konkretnych działań w tym zakresie. Nie nadmieniono jednak, że to właśnie zmiany klimatyczne są jedną z głównych przyczyn współczesnych migracji.

Rok później, w ramach szczytu G20 w Hamburgu (2017), think tank G20 Insights Platform, zajmujący się opracowywaniem rekomendacji dla decydentów grupy najbardziej rozwiniętych państw świata ${ }^{20}$, przygotował tzw. policy brief dotyczący zbudowania globalnego systemu zarządzania, uwzględniającego problem "uchodźców klimatycznych" ${ }^{21}$. W dokumencie podkreślono konieczność stworzenia ram prawnych i międzynarodowego 
mechanizmu ochrony dla ludzi decydujących się na opuszczenie swego miejsca zamieszkania ze względu na zmiany klimatu przejawiające się podnoszeniem się poziomu mórz, stepowieniem i pustynnieniem terenów rolniczo użytkowanych, zmianami w funkcjonowaniu ekosystemów, w szczególności utratą dostępu do wody oraz możliwości produkcji żywności. Autorzy dokumentu przyznali, że obecny system prawa międzynarodowego, jak również istniejące mechanizmy finansowe i instytucjonalne są niewydolne wobec narastającego problemu migracji klimatycznych. Zaproponowane rozwiązania objęły wezwanie IOM, IDMC, UNEP, Warszawskiego Międzynarodowego Mechanizmu Start i Szkód, czyli wszystkich ważniejszych organizacji i instytucji zajmujących się tą problematyką, do składania grupie G20 corocznych raportów na temat dynamiki zmian klimatu i migracji jako ich skut$\mathrm{ku}$, wezwanie stosownych organizacji do lepszego skoordynowania pomocy humanitarnej dla ofiar katastrof, przewidując zwiększenie częstotliwości ich występowania. Zdaniem autorów, G20 powinno zobowiązać się do przeznaczenia odpowiednich środków na zwiększenie jakości i skuteczności tej pomocy, a także do skoordynowania działań średnio- i długoterminowych na poziomie międzynarodowym i lokalnym. Wśród tych działań wymieniono: integrowanie migrantów w państwach przyjmujących, przeciwdziałanie ich dyskryminowaniu, podkreślanie korzyści ekonomicznych i kulturowych z ich obecności w społeczeństwie, jak również wezwanie decydentów i twórców polityk międzynarodowych i narodowych do tworzenia stosownych ram prawnych w celu zapewnienia odpowiedniej ochrony tym, których warunki klimatyczne zmusiły do migracji. Zaapelowano również, by problematyka migracji klimatycznych została na stałe włączona do agendy szczytów G20.

W deklaracji światowych przywódców opublikowanej po szczycie G20, posunięto się o krok dalej w stosunku do szczytu, który odbył się rok wcześniej. W części poświęconej „uznawaniu odpowiedzialności” wskazano katastrofy naturalne jako jedną z głównych przyczyn przymusowych migracji ${ }^{22}$. Niestety, nie stało się to przyczynkiem do debaty na temat wpływu zmian klimatu na przemieszczanie się ludności ani związku tych zmian z obecnym kryzysem migracyjnym. Przedstawione przez think tank G20 Insights Platform rekomendacje nie zostały uwzględnione w obradach, mimo że została poruszana problematyka zmian klimatu i porozumienia paryskiego. 


\section{OCENA POLITYKI I SYTUACJI PRAWNEJ UCHODŹCÓW KLIMATYCZNYCH}

W przypadku uchodźców klimatycznych trudności są podwójne. Fakt dokonujących się zmian klimatycznych jest bezdyskusyjny, ale niejednoznaczne są przyczyny tego stanu rzeczy. Chodzi np. o to, czy należy je przypisywać raczej zjawiskom naturalnym, czy działalności człowieka. Dyskusje na ten temat są zawsze interesujące, ale nie przynoszą konkretnych i realnych rozwiązań. Te wątpliwości nie powinny jednak być argumentami osłabiającymi zaangażowanie i działania podejmowane wobec wszystkich tych, którym niegościnna ziemia odmawia żywności i podstawowych dóbr. Dla zmniejszenia rozmiarów migracji i zmiany kierunku przemieszczania się ludzi - z myślą zarówno o nich, jak i sobie - wspólnota międzynarodowa powinna zintensyfikować swoje działania wspomagające i naprawcze in loco. To dawałoby im nadzieję na powrót do życia na własnej ziemi. Obraz tych „wygnańców ziemi” jest silnym apelem o angażowanie się wszystkich państw - poczynając od bogatych i rozwiniętych - które przecież w jakimś stopniu są odpowiedzialne za zmiany klimatu.

Działania podejmowane przez organizacje międzynarodowe, z ONZ na czele, wskazują, jaki kierunek obrała debata na temat migracji wywoływanych zmianami klimatu. Odnosi się wrażenie, że problem jest rozpatrywany niemal wyłącznie z uwzględnianiem wymiernych szkód i strat gospodarczych wywołanych katastrofami naturalnymi, przy jednoczesnym minimalizowaniu, albo nawet z pominięciem, rzeczywistych dramatów osobistych dotkniętych nieszczęściem ludzi (również zasługujących na ochronę ze strony praw człowieka).

Z uwagi na fakt, że porozumienie paryskie zostało ratyfikowane przez 160 państw, można zaryzykować stwierdzenie, że uznały one zmiany klimatyczne za istotną przyczynę migracji. Wiąże się to z koniecznością podjęcia stosownych działań w tym zakresie. Przygotowanie propozycji takich działań zostało zlecone grupie zadaniowej funkcjonującej w ramach Warszawskiego Międzynarodowego Mechanizmu Strat i Szkód. Rekomendacje mają dotyczyć głównie wzmocnienia systemów zarządzania ryzykiem związanym z występowaniem katastrof naturalnych, usuwania ich następstw oraz opracowania systemów kompensacji. Podobny kierunek został obrany 
przez inicjatywę Nansen, która ewoluując, przekształciła się w Platformę ds. wysiedleń na skutek katastrof (Platform on Disaster Displacement). Sama jej nazwa wskazuje, że za główną przyczynę przemieszczania się ludności uznano katastrofy ekologiczne.

Niestety, zawężenie debaty o migracjach klimatycznych do dwóch tylko obszarów, tj. nagłych katastrof i usuwania szkód, nie jest tendencją wszystkich zadowalającą. Takie rozumowanie jest zbyt wąskie, ponieważ ogranicza negatywny wpływ zmian klimatycznych do katastrof naturalnych, a przymusową migrację do ich szkodliwych konsekwencji. Tymczasem zmiany klimatyczne są zjawiskiem postępującym w czasie, a ich konsekwencje nie zawsze manifestują się w postaci nagłych katastrof. Powodują stopniowe przekształcanie się ekosystemu, sukcesywnie pogarszając warunki życiowe i zmuszając ludzi do poszukiwania dogodniejszych miejsc egzystencji. Decydujący się na migracje z terenów dotkniętych np. długotrwałą suszą nie zostaną zatem objęci ochroną przewidzianą dla ofiar katastrof naturalnych, gdyż zidentyfikowanie migrantów uciekających przed katastrofami naturalnymi jest o wiele łatwiejsze niż w przypadku osób, dotkniętych skutkami z wolna postępujących w czasie zmian klimatu. Jest bardziej prawdopodobne, że organy odpowiedzialne za udzielenie im ochrony czy pomocy uznają ich za migrantów ekonomicznych, a rzeczywiste/pierwotne (tzn. klimatyczne) przyczyny migracji nie zostaną w ogóle wzięte pod uwagę. Dla twórców polityk i strategii rozszerzenie zakresu ochrony na te osoby z pewnością stanowiłoby ogromne - możliwe, że przerastające realne możliwości - wyzwanie. Być może jest to jedną z przyczyn, dla której problem ten jest pomijany w globalnej debacie. Toteż nawet jeżeli w omawianych dokumentach zjawisko migracji jest postrzegane raczej jako negatywny skutek zmian klimatycznych, któremu trzeba zapobiegać, to w rzeczywistości odnosi się wrażenie, że chyba nikomu na działaniach zapobiegawczych, a tym bardziej naprawczych, nie zależy. Pytanie, które się tu nasuwa: dlaczego? - pozostaje, póki co, otwarte. Komentując zjawisko, zauważa się natomiast, że kontrolowana migracja może być skutecznym środkiem adaptacyjnym. Grupa doradcza w rekomendacjach do projektu porozumienia paryskiego zwróciła uwagę na wykorzystanie planowanych i kontrolowanych relokacji jako sposobu radzenia sobie ze skutkami zmian 
klimatu. Również w projekcie utworzenia centrum koordynacji migracji klimatycznych, nad którym debatowano podczas paryskiej konferencji klimatycznej, uwzględniono koordynowanie planowanych relokacji jako jedno z głównych zadań. Projekt niestety został odrzucony, a zagadnienie planowanych relokacji nie pojawiło się w dokumentach pokonferencyjnych, ani w planie działania grupy zadaniowej przy Warszawskim Międzynarodowym Mechanizmie Strat i Szkód.

Wśród głównych podmiotów zajmujących się problematyką migracji klimatycznych, jedyną organizacją, która zwróciła uwagę na wykorzystanie migracji w działaniach adaptacyjnych, jest IOM. Uznanie migracji za środek adaptacyjny do zmian klimatycznych jest jednym z celów utworzonej w ramach IOM Sekcji ds. Migracji, Środowiska i Zmian Klimatu, a także realizowanego projektu MECLEP.

Ponadto, należy zwrócić również uwagę na fakt, że omówione powyższej działania organizacji międzynarodowych i uchwalane dokumenty nie tworzą systemu międzynarodowej ochrony prawnej nawet dla łatwiejszych do zidentyfikowania ofiar katastrof naturalnych. Ustalenia porozumienia paryskiego nie mają mocy wiążącej dla stron konwencji, a inne dokumenty czy raporty przygotowywane przez organizacje międzynarodowe mają jedynie charakter informacyjny lub doradczy. Na lukę prawną i konieczność uchwalenia międzynarodowej konwencji lub dodatkowego protokołu do konwencji zaczęto zwracać uwagę już w latach 80. i 90. ubiegłego wieku, kiedy to pojawiło się pojęcie migrantów klimatycznych. Przedstawiciele środowisk akademickich przygotowali nawet całościowe projekty konwencji. Na szczególną uwagę zasługuje opracowany w 2008 r. projekt Konwencji o Międzynarodowym Statusie Migrantów Klimatycznych (Michel, 2008, s. 395-406), zakładający m.in. utworzenie Światowej Agencji dla Migrantów Klimatycznych (World Agency for Environmentally Displaced People) i Światowego Funduszu dla Migrantów Klimatycznych (World Fund for Environmentally Displaced People). Równie ambitny projekt dotyczący Konwencji o Uchodźcach Klimatycznych został przygotowany przez pracowników Harward Law School w 2009 r. Żadna $\mathrm{z}$ tych propozycji nie została jednak wykorzystana. W konsekwencji, do dnia dzisiejszego nie istnieje instrument prawny, który regulowałby sytuację migrantów klimatycznych. Jako jeden z powodów tego stanu rzeczy 
można wskazać kwestie polityczne, w tym przede wszystkim opór krajów wysokorozwiniętych, które zapewne obawiają się wzmożonego i niekontrolowanego napływu migrantów.

Brak chęci i inicjatyw na tym polu jest widoczny w samej ONZ. Wysoki Komisarz Narodów Zjednoczonych ds. Uchodźców przyjął stanowisko, że z punktu widzenia ekonomii prawnej lepszym rozwiązaniem będzie skupienie się na wspieraniu lokalnych rozwiązań systemowych i działaniach na poziomie narodowym i regionalnym, jak również zachęcanie państw członkowskich do zawierania umów multilateralnych i współpracy regionalnej ${ }^{23}$, niż nowa wiążąca konwencja na poziomie międzynarodowym, pociągająca za sobą zazwyczaj mało skuteczne (dla potrzebujących) zmiany legislacyjne.

\section{Literatura}

Cournil, C. (2011), The Protection of „Environmental Refugees” in International Law. W: É. Piguet, A. Pécoud, P. de Guchteneire (red.), Migration and Climate Change, Cambridge: Cambridge University Press and UNESCO, s. 359-387. ISBN 9781107014855.

Docherty, B. i Gianni, T. (2009), Confronting a Rising Tide: A Proposal for a Convention on Climate Change Refugees, „Harvard Environmental Law Review” Nr 39, s. 349-403. ISSN 0147-8257.

Epiney, A. (2011), „Environmental refugees”: aspects of international state responsibility. W: É. Piguet, A. Pécoud, P. de Guchteneire (red.), Migration and Climate Change, Cambridge: Cambridge University Press and UNESCO, s. 388-415. ISBN 9781107014855.

Michel, P. (2008), Draft convention on the international status of environmentally displaced persons, "Revue Européenne de Droit de l'Environnement” $\mathrm{Nr} 4$, s. 395-406. ISSN 1283-8446.

\section{Akty prawne i dokumenty}

Decyzja 3/CP.18, Konferencja Klimatyczna w Doha, 2012, http://unfccc.int/resource/docs/2012/cop18/eng/08a01.pdf\#page=21 (dostęp: 21.09.2017).

Decyzja 1/CP.16, Konferencja Klimatyczna w Cancun, 2011, https://unfccc.int/resource/docs/2010/cop16/eng/07a01.pdf (dostęp: 21.09.2017). 
Decyzja ramowa CP.21, Konferencja Klimatyczna w Paryżu, 2015, https://unfccc.int/ resource/docs/2015/cop21/eng/109r01.pdf (dostęp: 20.09.2017).

Porozumienie Paryskiez dnia 4.11.2016, http://unfccc.int/files/essential_background/ convention/application/pdf/english_paris_agreement.pdf (dostęp: 10.09.2017).

The Sendai Framework on Disaster Risk Reduction 2015-2030, http://www.unisdr. org/files/43291_sendaiframeworkfordrren.pdf (dostęp: 10.10.2017).

United Nations Framework Convention on Climate Change, http://unfccc.int/2860. php (dostęp: 10.09.2017).

\section{Raporty}

Environmental Migration Portal, IOM and migration, environment and climate change, http://www.environmentalmigration.iom.int/iom-and-migration-environmentand-climate-change-mecc (dostęp: 09.10.2017).

G20 Insight, Building Global Governance for 'Climate Refugees', http://www.g20chn. com/xwzxEnglish/sum_ann/201609/t20160906_3397.html (dostęp: 21.10.2017).

G20 Leaders' Declaration Shaping an interconnected world, Hamburg 2017, https:// www.g20.org/Content/EN/_Anlagen/G20/G20-leaders-declaration.pdf?__blo$\mathrm{b}=$ publicationFile\&v=11 (dostęp: 21.10.2017).

Human Mobility in the context of climate change UNFCC-Paris COP-21, 2015, http:// www.internal-displacement.org/assets/publications/2015/201511-human-mobility-in-the-context-of-climate-change-unfccc-Paris-COP21.pdf (dostęp: 11.09.2017).

IOM Outlook on Migration, Environment and Climate Change, International Organization for Migration 2017, http://publications.iom.int/system/files/pdf/mecc outlook.pdf (dostęp: 29.09.2017).

Summary of the Meetings of the Executive Committee of the Warsaw International Mechanism for Loss and Damage associated with Climate Change Impacts, http:// unfccc.int/files/adaptation/groups_committees/loss_and_damage_executive_committee/application/pdf/summary_of_decisions_5_feb.pdf (dostęp: 11.10.2017).

Summary of proceedings of the first meeting of the Task Force on Displacement, the Executive Committee of the Warsaw International Mechanism for Loss and Damage, http://unfccc.int/files/adaptation/workstreams/loss_and_damage/application/ pdf/tfd_1_summary_of_proceedings.pdf (dostęp: 11.10.2017).

Terms of References of the Task Force on Displacement, http://unfccc.int/files/adaptation/groups_committees/loss_and_damage_executive_committee/application/ pdf/tor_task_force.pdf (dostęp: 10.10.2017). 
The Nansen Initiative, Agenda for the protection of the cross-border displaced persons in the context of disasters and climate change, 2015, https://nanseninitiative.org/ wp-content/uploads/2015/02/PROTECTION-AGENDA-VOLUME-1.pdf (dostęp: 14.09.2017).

The UN Migration Agency, COP21 Paris Agreement: A stepping stone for climate migrants, https://weblog.iom.int/cop21-paris-agreement-stepping-stone-climatemigrants (dostęp: 11.09.2017).

Working Group on the Durban Platform for Enhanced Action, Working Document on Adaptation and Loss and Damage, http://unfccc.int/resource/docs/2015/adp2/ eng/01.pdf (dostęp: 2.11.2017).

Workplan of the task force on displacement, http:/unfccc.int/files/adaptation/workstreams/loss_and_damage/application/pdf/tfd_workplan.pdf (dostęp: 11.10.2017).

UNCHR, Climate change and statelessness, https://www.un.org/ruleoflaw/files/4a2d189d3.pdf (dostęp: 10.09.2017).

\section{Strony internetowe}

Environmental Migration Portal, http://www.environmentalmigration.iom.int/ (dostęp: 10.09.2017).

G20 Insight Portal, http://www.g20-insights.org/about/ (dostęp: 11.09.2017).

The Nansen Initiative, disaster induced, cross-border displacement, https://www. nanseninitiative.org/secretariat/ (dostęp: 10.09.2017).

United Nations High Commissioner for Refugees, http://www.unhcr.org/dach/chde/ (dostęp: 10.09.2017).

\section{Endnotes}

${ }^{1}$ Decyzja 1/CP.16, Konferencja Klimatyczna w Cancun.

2 UNCHR, The Environment and Climate Change, UNCHR, 2015, s. 11.

${ }^{3}$ Decyzja 3/CP.18, Konferencja Klimatyczna w Doha, 2012.

${ }^{4}$ Human Mobility in the context of climate change UNFCC - Paris COP-21, 2015.

5 The Nansen Initiative, disaster induced, cross-border displacement.

${ }^{6}$ UNHCR, The Environment..., op. cit., s. 9.

7 The Nansen Initiative, Agenda for the protection of the cross-border displaced persons in the context of disasters and climate change, 2015, s. 7, 10. 
8 Porozumienie paryskie z 4.11.2016.

9 Decyzja ramowa CP.21, Konferencja Klimatyczna w Paryżu, 2015.

10 The UN Migration Agency, COP21 Paris Agreement: A stepping stone for climate migrants.

${ }^{11}$ Summary of the Meetings of the Executive Committee of the Warsaw International Mechanism for Loss and Damage associated with Climate Change Impacts.

12 Ibidem.

${ }^{13}$ Summary of proceedings of the first meeting of the Task Force on Displacement, the Executive Committee of the Warsaw International Mechanism for Loss and Damage.

14 Terms of References of the Task Force on Displacement.

15 Workplan of the task force on displacement.

16 The Sendai Framework on Disaster Risk Reduction 2015-2030.

17 Art. 30 (l), To encourage the adoption of policies and programmes addressing disaster-induced human mobility to strengthen the resilience of affected people and that of host communities, in accordance with national laws and circumstances.

18 Environmental Migration Portal, IOM and migration, environment and climate change.

19 Par. 44 G20 Insight, Building Global Governance for 'Climate Refugees'.

20 G20 Insight Portal.

${ }^{21}$ G20 Insight, Building Global Governance..., op. cit.

22 Par. 39 G20 Leaders' Declaration Shaping an interconnected world, Hamburg 2017.

${ }^{23}$ UNCHR, Climate change and statelessness. 
